\title{
Analisis Number Sense Ditinjau dari Gaya Kognitif Reflektif-Impulsif
}

\author{
(Number Sense Analysis Judging from the Reflective-Impulsive Cognitive Style)
}

\author{
Laylatul Fitri $^{1}$, Lely Andriana Rachmadwati ${ }^{1}$, Julia Putri Riska Ayati ${ }^{1}$, Novita Eka \\ Muliawati $^{2}$ \\ ${ }^{1}$ Mahasiswa Program Studi Pendidikan Matematika STKIP PGRI Tulungagung;Co-author: \\ irfiqna03@gmail.com \\ ${ }^{2}$ Dosen Prodi Pendidikan Matematika STKIP PGRI Tulungagung
}

\begin{abstract}
Abstrak: Penelitian ini bertujuan untuk mendeskripsikan 1) Number sense siswa ditinjau dari gaya kognitif reflektif; dan 2) Number sense siswa ditinjau dari gaya kognitif impulsif. Jenis penelitian yang digunakan pada penelitian ini adalah penelitian kualitatif dengan instrumen penelitian berupa tes MFFT, soal tes number sense dan wawancara. Pemberian tes MFFT bertujuan untuk mengetahui siswa mana yang memiliki gaya kognitif reflektif dan mana siswa yang memiliki gaya kognitif impulsif. Tes MFFT diberikan pada siswa kelas X TKR 2 SMK Negeri 2 Tulungagung dengan siswa sejumlah 36 siswa. Tes number sense diberikan kepada 2 sampel yang telah terpilih berdasarkan gaya kognitif. Hasil penelitian ini menunjukkan bahwa siswa yang memiliki gaya kognitif reflektif menjawab lebih lama dibandingkan siswa dengan gaya kognitif impulsif, memiliki jawaban yang lebih tepat dibandingkan siswa bergaya kognitif impulsif, dan memiliki alasan sendiri terhadap jawaban dibandingkan siswa dengan gaya kognitif impulsif. Kemampuan number sense siswa dengan gaya kognitif reflektif lebih bagus dibandingkan siswa dengan gaya kognitif impulsif.
\end{abstract}

Kata kunci: Gaya Kognitif Impulsif, Gaya Kognitif Reflektif, Number sense.

\begin{abstract}
This study aims to describe 1) the students' sense of sense in terms of reflective cognitive style; and 2) Number sense of students in terms of impulsive cognitive style. The type of research used in this study is qualitative research with research instruments in the form of MFFT tests, number sense test questions and interviews. The MFFT test aims to find out which students have reflective cognitive style and which students have impulsive cognitive style. The MFFT test is given to class X TKR 2 students of SMK Negeri 2 Tulungagung with 36 students. Number sense tests are given to 2 selected samples based on cognitive style. The results of this study indicate that students who have a reflective cognitive style answer longer than students with impulsive cognitive style, have more precise answers than students with impulsive cognitive style, and have their own reasons for answers compared to students with impulsive cognitive style.
\end{abstract}

Keywords: Impulsive Cognitive Style, Number sense, Reflective Cognitive Style.

\section{PENDAHULUAN}

Matematika merupakan suatu bidang yang memiliki peran penting didalam Pendidikan. Matematika merupakan salah satu mata pelajaran yang diajarkan kepada siswa sejak sekolah dasar hingga pergutuan tinggi. Asalah kehidupan nyata juga tidak terlepas dari matematika, misalnya proses jual beli, pengukuran tanah dan lain-lain. Dengan demikian, matematika memang sangat penting untuk dipelajari untuk bekal siswa menjalani kehidupan nyata di masyarakat.

Untuk mempelajari mengenai bilangan dalam matematika, number sense memiliki peran yang sangat penting. Oleh karena itu, number sense siswa perlu dilatih dan dikembangkan dengan baik dan benar agar kemampuan number sense sangat bermanfaat bagi siswa dalam pemecahan masalah matematika terutama pada hal yang berkaitan dengan bilangan.

Fennel and Landis (1994) seperti yang dikutip dari Masriyah \& Hanifah (2016) menyebutkan bahwa number sense adalah sebuah kesadaran dan pemahaman seseorang mengenai bilangan, hubungan antar bilangan, tingkat kepentingan, dan perhitungannya dengan menggunakan mental matematika. 
Bobis (1996) seperti yang dikutip dari Masriyah \& Hanifah (2016) berpendapat bahwa number sense adalah sebuah konsep yang terorganisasi mengenai suatu bilangan. Hal ini berarti number sense sangat membantu seseorang untuk memahami bilangan dan dapat menyelesaikan masalah-masalah yang berhubungan dengan matematika.

Kemampuan number sense merupakan kecakapan sesorang siswa dalam penyelesaikan pertanyaan yang berkaitan dengan bilangan dengan menggunakan tafsiran perhitungan dan atau tanpa menggunakan algoritma matematika.

Perkembangan number sense dimulai sejak dini, ketika anak mengenali representasi dari bilangan kecil (Jordan, 2010) dalam (Mufidah, 2017). Kemampuan number sense akan berkembang sesuai tahapan-tahapan yang bervariasi untuk masing-masing individu.

Number sense yang bervariasi dapat disebabkan oleh pengalaman belajar matematika dan kemamapuan matematika serta yang menjadi sorotan dalam penelitian ini, yaitu gaya kognitif (Mufidah, 2017). Seseorang yang memiliki kemampuan number sense yang baik adalah individu yang gemar dan familiar terhadap bilangan. Misalnya, memahami arti bilangan, manfaat dari bilangan dan mampu menginterpretasikannya, dan lain-lain.

Amirulloh dan Budiarto (2014) menyatakan bahwa mengembangkan sebuah kerangka yang dapat digunakan untuk menilai kemampuan number sense. kerangka ini tidak melihat faktor yang dapat mempengaruhi kemampuan number sense, tetapi dapat dijadikan tolak ukur untuk melihat atau menilai kemampuan number sense yang dimiliki siswa. kerangka tersebut dirumuskan menjadi six number sense strands dengan rincian sebagai berikut.

1. understanding and use of the meaning
and size of numbers
2. understanding and use of equivalent forms and representations of numbers

3. understanding the meaning and effect of operations

4. understanding and use of equivalent expressions

5. computing and counting strategies

6. measurement benchmarks.

Lebih lanjut Amirulloh and Budiarto (2014) memberikan catatan sebagai berikut. Assess childrens' number sense to the first five strands in the number strand number five in the number sense framework. The sixth strand, though is as important if left for further or subsequent study Berdasarkan kutipan di atas dapat diartikan bahwa untuk mengukur kemampuan number sense siswa bisa menggunakan five number sense strands sebagai indikator dalam membuat soal. Sedangkan untuk six number sense strands digunakan untuk mengukur siswa yang memiliki kemampuan atau jenjang pendidikan yang lebih tinggi.

Kemampuan seseorang dalam memecahkan masalah sudah pasti berbeda-beda. Sering kali dengan cara penyelesaian yang berbeda akan memiliki jawaban yang sama. Hal ini adalah pengaruh dari gaya kognitif siswa yang berbeda-beda pula.

Gaya kognitif merupakan cara penerimaan dan pengelolaan sikap individu terhadap informasi, maupun kebiasaan yang berkaitan dengan dunia belajar. Sejumlah gaya kognitif sudah diidentifikasi dalam beberapa pustaka, Putri, Dwijanto, \& Sugiman (2017) mengatakan bahwa salah satu dimensi gaya kognitif yang memperoleh perhatian paling besar dalam pengkajian anak berkesulitan belajar yaitu gaya kognitif impulsif dan reflektif (menjawab permasalahan secara cepat tetapi banyak kesalahan dan menjawab permasalahan lebih lambat tetapi sedikit kesalahan).

Gaya kognitif reflektif dan impulsif menggambarkan kecenderungan anak yang tetap untuk menunjukkan cepat atau 
lambat waktu menjawab terhadap situasi masalah dengan ketidakpastian jawaban yang tinggi. Siswa yang bergaya kognitif impulsif cenderung cepat dalam menyelesaikan masalah tetapi tingkat kesalahan jawaban sangat tinggi. Sedangkan siswa yang bergaya kognitif reflektif lambat dalam menyelesaikan masalah, cermat, teliti dan hati-hati sehingga tingkat kesalahan jawaban sangat rendah.

Berikut disajikan perbedaan siswa dengan gaya kognitif reflektif dan gaya kognitif impulsif:

\section{Tabel 1. Perbedaan siswa gaya kognitif reflektif dan impulsif}

\begin{tabular}{|c|c|}
\hline Siswa reflektif & Siswa impulsive \\
\hline Untuk menjawab digunakan waktu lama & $\begin{array}{l}\text { Cepat memberikan jawaban tanpa } \\
\text { mencermati terlebih dahulu }\end{array}$ \\
\hline Jawaban lebih tepat (akurat) & Pendapat kurang akurat \\
\hline Menyukai masalah analog & $\begin{array}{l}\text { Tidak menyukai jawaban masalah yang } \\
\text { analog }\end{array}$ \\
\hline $\begin{array}{l}\text { Menggunakan paksaan dalam } \\
\text { mengeluarkan berbagai kemungkinan }\end{array}$ & $\begin{array}{l}\text { Menggunakan hypothesis scaning; yaitu } \\
\text { merujuk pada satu kemungkinan saja }\end{array}$ \\
\hline Strategis dalam menyelesaikan masalah & $\begin{array}{l}\text { Kurang strategis dalam menyelesaikan } \\
\text { masalah }\end{array}$ \\
\hline \multicolumn{2}{|l|}{ Reflektif terhadap kesustraan IQ tinggi } \\
\hline \multicolumn{2}{|l|}{ Berfikir sejenak sebelum menjawab } \\
\hline \multicolumn{2}{|l|}{ Kelainan dari segi kognitif } \\
\hline Berargumen lebih matang & \\
\hline
\end{tabular}

Untuk menentukan kelompok siswa gaya kognitif reflektif dan impulsif, peneliti menggunakan rata-rata waktu dan rata-rata frekuensi jawaban siswa dengan kriteria sebagai berikut:

1. Siswa gaya kognitif reflektif yaitu yang memiliki rata-rata waktu lebih dari median rata-rata waktu dan rata-rata

\section{METODE PENELITIAN}

Penelitian ini merupakan penelitian deskriptif dengan menggunakan pendekatan kualitatif. Sesuai dengan permasalahan yang ada, tujuan dari penelitian ini adalah mendeskripsikan mengenai kemampuan number sense siswa ditinjau dari gaya kognitif reflektif dan mendeskripsikan mengenai kemampuan number sense siswa ditinjau dari gaya kognitif impulsif.

Subjek penelitian adalah 2 siswa yang terpilih dari kelas X TKR 2 SMK Negeri 2 Tulungagung dengan kriteria 1 siswa dengan gaya kognitif reflektif dan 1
Sumber: Kagan dalam (Wali, 2012)

frekuensi kurang dari atau sama dengan median rata-rata frekuensi.

2. Siswa gaya kognitif impulsif yaitu yang memiliki rata-rata waktu kurang dari atau sama dengan median rata-rata waktu dan rata- rata frekuensi lebih dari median rata-rata frekuensi.

siswa dengan gaya kognitif impulsif yang didapat dari pemberian tes MFFT kepada seluruh siswa kelas $\mathrm{X}$ TKR 2 yang berjumlah 36 siswa.

Instrumen pendukung yang digunakan berupa tes yang terdiri dati tes MFFT dan tes number sense serta wawancara. Tes number sense diberikan untuk mengukur kemampuan number sense siswa dan wawancara digunakan untuk menggali informasi bagaimana siswa mendapatkan jawaban dan alasan darimana jawabannya berasal. Pemilihan subjek ini dilakukan dengan cara snowball 
sampling. Instrumen tes MFFT yang digunakan dalam penelitian ini merupakan tes Putri et al (2017) yaitu 2 item soal percobaan dan 13 item soal.

Bentuk soal dari tes MFFT ini adalah diberikan 1 gambar sebagai soal, kemudian diberikan 8 gambar dimana 1 gambar sama dengan gambar pada soal.
Siswa diminta untuk memilih 1 dari 8 gambar yang tersedia. Gambar yang diminta untuk dipilih adalah gambar yang sama persis dengan gambar pada soal.

Tes number sense dibuat dengan materi bilangan pecahan dan desimal. Adapun indikator dari soal tersebut adalah sebagai berikut:

Tabel 3.1 Tabel Indikator Tes Number Sense

\begin{tabular}{|c|c|c|}
\hline No & Indikator Number Sense & Indikator Soal tes Number sense \\
\hline 1 & Number Concept & $\begin{array}{l}\text { Membandingkan nilai dua pecahan atau desimal } \\
\text { Mengurutkan bilangan pecahan atau desimal } \\
\text { Menunjukkan terdapat pecahan atau desimal lain } \\
\text { diantara } 2 \text { bilangan }\end{array}$ \\
\hline 2 & Multiple Representations & $\begin{array}{l}\text { Menentukan letak pecahan dan desimal dalam } \\
\text { garis bilangan } \\
\text { Menyatakan pecahan dalam daerah yang di arsir, } \\
\text { gambar ataupun sebaliknya }\end{array}$ \\
\hline 3 & Effect of Operations & $\begin{array}{l}\text { Mengemukakan akibat dari operasi pada dua } \\
\text { bilangan } \\
\text { Menilai apakah bilangan sebagai hasil hasil } \\
\text { operasi yang diperoleh masuk akal }\end{array}$ \\
\hline 4 & Equivalent Expressions & $\begin{array}{l}\text { Menentukan ekspresi matematika lain yang } \\
\text { ekuivalen dengan ekspresi matematika yang } \\
\text { diberikan }\end{array}$ \\
\hline 5 & $\begin{array}{l}\text { Computing and Counting } \\
\text { strategies }\end{array}$ & $\begin{array}{l}\text { Menggunakan strategi (estimasi, menghitung } \\
\text { dikertas, perhitungan mental) yang efektif dalam } \\
\text { menyelesaikan masalah matematika }\end{array}$ \\
\hline 6 & Measurement Benchmarks & $\begin{array}{l}\text { Menyelesaikan soal matematika yang berkaitan } \\
\text { dengan situasi pengukuran }\end{array}$ \\
\hline
\end{tabular}

\section{HASIL PENELITIAN}

Dari hasil tes MFFT diperoleh gaya kognitif dari 36 siswa yaitu gaya kognitif tipe reflektif dan gaya kognitif tipe impulsif. Dari tes tersebut dipilih 2 siswa dengan kriteria 1 dengan gaya kognitif reflektif dan 1 dengan gaya kognitif impulsif. Setelah terpilih 2 sampel, sampel terpilih diberikan tes number sense. Setelah selesai mengerjakan, peneliti mengajukan beberapa pertanyaan untuk menggali informasi mengenai jawaban dari soal yang ada. Berikut adalah jawaban dari siswa sebagai sampel terpilih.

\begin{tabular}{llll}
\hline No & \multicolumn{2}{c}{ Soal Number Sense } & \multicolumn{2}{c}{ Strategi Number sense siswa } \\
\hline 1 & Dua lempengan plat dengan & Siswa dengan gaya kognitif reflektif \\
ketebalan masing-masing lempeng & memberikan alasan yaitu siswa melihat angka \\
& $\mathrm{A}=2,25 \mathrm{~mm}$ dan lempeng plat $\mathrm{B}=$ & di belakang koma, karena 2 lebih kecil dari 5, \\
& $2,5 \mathrm{~mm}$. lempengan plat manakah & maka lempeng yang lebih tebal adalah 2,5 \\
& yang lebih tebal? & $\mathrm{mm}$ & \\
& Siswa dengan gaya kognitif impulsif \\
& memberikan alasan nilai 2,5 sama dengan \\
& 2,50 sehingga 2,5 mm lebih tebal dari pada \\
\hline
\end{tabular}




\begin{tabular}{rr}
\hline No & Soal Number Sense \\
\hline 2 Urutkan bilangan dibawah ini dari \\
terkecil ke terbesar \\
$\frac{3}{4}, \frac{5}{7}, \frac{3}{5}, \frac{6}{9}$
\end{tabular}

3 Berapa banyak bilangan decimal antara $\frac{3}{7}$ dan $\frac{4}{7}$ ? Sebutkan

4 Urutkanlah bilangan-bilangan berikut, kemudian tentukan letaknya dalam garis bilangan

$$
\frac{2}{3},-1, \frac{1}{2}
$$

5 Daerah yang diarsir dibawah ini menunjukkan pecahan

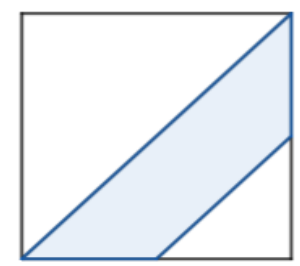

6 Tempatkan tanda koma pada hasil perkalian $115,4 \times 0,325=37505$

7 Jika suatu bilangan dengan 3 angka dikalikan dengan bilangan 3 angka maka hasilnya....

a. Selalu 3 angka

b. Selalu 4 angka

c. Selalu 5 angka

d. Kadang-kadang 5 angka

8 Nilai yang sama dengan $36,285 \div$ 1,23 adalah

\section{Strategi Number sense siswa}

$2,25 \mathrm{~mm}$

Kedua sampel memberikan alasan yang sama, yaitu bilangan-bilangan tersebut disamakan penyebutnya, sehingga bilangan dengan mudah diurutkan

Siswa dengan gaya kognitif reflektif menyebutkan bahwa terdapat banyak bilangan dan tak terhitung (artinya tidak terhingga) antara 2 bilangan tersebut, sedangkan siswa dengan gaya kognitif impulsif menyebutkan bahwa tidak ada bilangan antara $\frac{3}{7}$ dan $\frac{4}{7}$ karena selisih dari 4 dan 3 adalah 0

Kedua sampel menyebutkan alasan yang sama cara mengurutkan bilangan adalah menyamakan penyebut. Bilangan yang sudah urut kemudian diletakkan pada garis bilangan

Kedua sampel memberikan jawaban dengan membagi persegi menjadi segitiga sebanyak 8 bagian. Dan menjawab $\frac{3}{8}$

Siswa dengan gaya kognitif Reflektif memilih untuk melakukan perkalian susun untuk menemukan jawabannya sehingga jawaban yang diperoleh tepat, yaitu 37,505

Siswa dengan gaya kognitif impulsif, memberikan jawaban 3,7505 dengan menghitung banyaknya angka dibelakang koma pada soal. Yaitu ada 4 sehingga jawaban harus ada 4 angka di belakang koma

Siswa dengan gaya kognitif reflektif menjawab poin D. Kadang-kadang 5. Karena siswa ini menghitung beberapa bilangan dengan 3 angka dan hasilnya berbeda.

Siswa dengan gaya kognitif impulsif menjawab poin C. Selalu 5, karena siswa tersebut mencoba sebanyak 1 kali dan mendapat jawaban sebanyak 5 angka

Kedua siswa memberikan alasan yang sama, dengan menghitung maju mundurnya koma, didapat jawaban yang tepat, yaitu: C. $3628,5 \div 123$ 


\section{PEMBAHASAN}

Hasil tes number sense dan wawancara kepada subjek adalah sebagai berikut. siswa yang memiliki gaya kognitif reflektif memiliki hitungan waktu untuk menjawab lebih lama di bandingkan dengan siswa yang memiliki gaya kognitif impulsif. Hal ini sesuai dengan pendapat Nasution (2008) yaitu siswa yang memiliki gaya kognitif impulsif cenderung mengambil keputusan dengan cepat tanpa memikirkannya secara mendalam. Sebaliknya, siswa yang memiliki gaya kognitif reflektif cenderung mempertimbangkan segala alternatif sebelum mengambil keputusan dalam situasi yang tidak mempunyai penyelesaian yang mudah.

Siswa yang memiliki gaya kognitif reflektif lebih mengutamakan logika berpikirnya dan mencerna apa yang dtinyakan soal sehingga kemampuannya dalam memahami masalah termasuk dalam jangka waktu yang lama jika dibandingkan dengan siswa dengan gaya kognitif impulsif. Namun, lamanya waktu menjawab soal tersebut tidak berarti siswa bergaya kognitif reflektif memerlukan waktu yang lama dalam menyelesaikan soal. Hitungan waktu tersebut maksudnya siswa dengan gaya kognitif reflektif lebih maksimal dalam memahami sampai menyelesaikan soal yang diberikan. Berbeda dengan siswa dengan gaya kognitif impulsif, mereka cenderumg lebih cepat dalam menjawab namun kecepatan menjawab

\section{KESIMPULAN DAN SARAN}

Berdasarkan analisis data dan pembahasan di atas, dapat diambil keputusan sebagai berikut:

1. Siswa dengan gaya kognitif reflektif memiliki hitungan waktu untuk menjawab lebih lama dibandingkan dengan siswa dengan gaya kognitif impulsif.

2. Siswa dengan gaua kognitif reflektif memberikan jawaban yang lebih tepat

\section{DAFTAR PUSTAKA}

Arvyaty, Salim dan Maryanti, Era. 2018. Teaching Material Mathematics with tersebut tanpa didasari pemikiran yang logis. Mereka hanya menjawab sekedarnya, bahkan jauh dari apa yang ditanyakan pada soal. Siswa dengan gaya kognitif impulsive, cenderung asal menjawab terhadap soal yang diberikan. Karena menjawabnya cepat dan asal, maka jawabannya sudah jelas kurang tepat.

Siswa yang memiliki gaya kognitif reflektif memberikan jawaban yang lebih tepat dari pada siswa yang memiliki gaya kognitif impulsif. Hal ini sesuai dengan pendapat dari Desmita (2010) yang mengemukakan bahwa siswa yang memiliki gaya kognitif impulsif memberikan respon yang cepat, tetapi cenderung melakukan kesalahan dalam proses tersebut. Sebaliknya siswa dengan gaya kognitif reflektif cenderung menggunakan lebih banyak waktu untuk merespon dan merenungkan akurasi jawaban, sehingga cenderung memberikan jawaban secara benar. Siswa dengan gaya kognitif reflektif memiliki alasan yang berbeda dengan yang diajarkan guru, sedangkan siswa dengan gaya kognitif impulsif memberikan alasan atas jawabannya sesuai dengan yang diajarkan guru di sekolah. Hal ini sesuai dengan penelitian yang dilakukan oleh Warli (2010) seperti yang dikutip dari Puspita \& Wijayanti (2016) bahwa siswa yang bergaya kognitif reflektif mempunyai kreativitas pemecahan yang lebih baik dari pada siswa bergaya kognitif impulsif

dari pada siswa yang memiliki gaya kognitif impulsif.

3. Siswa dengan gaya kognitif reflektif memiliki alasan yang berbeda dengan yang diajarkan guru, sedangkan siswa dengan gaya kognitif impulsive memberikan alasan jawaban sesuai dengan rumus yang diajarkan guru.

Penelitian ini diharapkan dapat mempertimbangkan konsep number sense pada bilangan lainnya.

\section{a Metacognitive Approach Guidance, Journal of Education and}


Learning (EduLearn), 12 (2) : 306310.

Daryanto. 2009. Panduan Proses Pembelajaran Kreatif \& Inovatif. Jakarta: Av Publisher.

Hamalik, Umar. 2002. Perencanaan Pengajaran Berdasarkan Pendekatan Sistem. Jakarta: Bumi

Amirulloh, A. F., \& Budiarto, M. T. 2014. Kemampuan Number Sense Siswa Kelas VIII SMP dilihat dari perbedaan jenis kelamin.

Desmita. 2010. Psikologi Perkembangan Peserta Didik.

Masriyah, \& Hanifah, U. (2016). Number Sense Siswa SMP Ditinjau Dari Gaya Kognitif. Prosiding Seminar Nasional Pendidikan Matematika 2016.

Mufidah, I. 2017. Profil Number Sense Siswa SD pada Materi Pecahan Ditinjau dari Gaya Kognitif Object Imagery , Spatial Imagery dan Verbal. Jurnal Matematika KreatfInovatif, 8(2), 208-214.

Nasution. 2008. Berbagai Pendekatan dalam Proses Belajar dan Mengajar.

Puspita, A. Y. A., \& Wijayanti, P. 2016. Profil Pemecahan Masalah Matematika Siswa Pada Materi Segiempat Ditinjau Dari Gaya Kognitif Reflektif Dan Impulsif. Jurnal Ilmiah Pendidikan Matematika Mathedunesa.

Putri, L., Dwijanto, \& Sugiman. 2017. Analisis Kemampuan Komunikasi Matematis dan Rasa Percaya Diri Siswa SMKKelas $X$ pada Pembelajaran Geometri Model Van Hiele Ditinjau dari Gaya Kognitif. Unnes Journal of Mathematics Education, 6 (1), 97-107.

Kramarski, B. and Mevarech, Z. 1997. Cognitive - Metacognitive Training within a Problem Solving Based
Logo Environment. British Journal of Educational Psychology, 67: 425-445.

Kramarski, B \& Mizarchi. 2004. Enhancing Mathematical Literacy with The Use of Metacognitive Giudance in Forum Discussion. Proceedings of the 28th Conference of the International Group for the Psychology of Mathematics Education.

Leavitt, Harold J. 2005. Psikologi Manajemen. Alih Bahasa: Muslichah Zarkasi. Jakarta: Erlangga. 